\title{
ІДЕНТИФІКАЦІЯ РИЗИКІВ БУДІВНИЦТВА ТА ЕКСПЛУАТАЦІї АВТОМОБІЛЬНИХ ДОРІГ
}

\author{
Деділова Т.В., канд. екон. наук, доцент \\ Харківський національний автомобільно-дорожній університет \\ Юрченко О.В., канд. екон. наук, доцент \\ Сумський національний аграрний університет
}

Постановка проблеми. Транспортна система України є індикатором соціально-економічного розвитку держави в стратегічному вимірі, при цьому мережа автомобільних доріг як їі невід'ємна складова виступає об'єднуючою ланкою між галузями національної економіки. Технічний стан автомобільних доріг зумовлює як стан економіки країни в цілому, так і стан економіки на рівні окремо взятих регіонів. Досконалі автомобільні дороги в майбутньому здатні підвищити ефективність використання основних фондів українських підприємств, оптимізувати потоки матеріальних і трудових ресурсів, підвищити продуктивність праці в окремих іiі галузях тощо. На жаль, на теперішньому етапі функціонування вітчизняного транспортного комплексу експлуатаційний стан автомобільних доріг залишається й досі незадовільним. Крім того, реформування дорожнього комплексу України все більше стикається з новими викликами, зумовленими системною економічною кризою в державі, підвищенням рівня екологічних вимог щодо проєктування та експлуатації автошляхів, залученням нових форм інвестування в їх розвиток, зростанням обсягів вантажного трафіку тощо. За своєю сутністю зазначені виклики мають характерні ознаки ризиків, дослідження й ідентифікація яких потребують розроблення відповідного теоретико-методологічного та методичного забезпечення.

Аналіз остатніх досліджень і публікацій. Оскільки діяльність підприємств дорожнього господарства можна розглядати у декількох аспектах (технічному, інвестиційному, фінансово-економічному, проєктному, управлінському тощо), отже й дослідження природи ризиків будівництва та експлуатації автомобільних доріг відповідними суб'єктами господарювання слід розглядати за окремими напрямами. 3 позиції того, що дорожні підприємства за своєю суттю відносяться до будівельних підприємств, можна стверджувати, що ризики дорожнього будівництва та експлуатації - це, перш за все, ризики будівництва. Так, Воскобіник О.П. і Семко О.В. [1] в своїх дослідженнях висвітлюють проблеми управління технічними ризиками у будівництві. В свою чергу, технічні ризики в проєктах автомобільних доріг також розглядають Канін О.П. і Татусь В.В. [2]. Питання мінімізації, запобігання і страхування фінансових та інвестиційних ризиків в будівництві розкрито в роботах Свідрик T.I. та Борщук I.В. [3], Серьогіна С.C. [4], в дорожньому будівництві - в роботах Корнієцького О.В. [5], Цімошинської О.В. [6]. Особливу увагу визначенню ступеня екологічних ризиків при будівництві 
та експлуатації автомобільних доріг приділяють такі дослідники, як Рутковська І.А., Герасименко А.В. [7], Богінська О.Л. [8], Зюзюн В.I. [9] та ін.

Невирішені складові загальної проблеми. Проведений аналіз останніх досліджень i публікацій за обраною тематикою засвідчив, що питання, пов'язані 3 ідентифікацією ризиків, які виникають при будівництві та експлуатації автошляхів, до теперішнього часу не є систематизованими 3 позиції їх класифікаційного розмежування, отже, виникає об'єктивна необхідність розроблення відповідного теоретико-методичного забезпечення.

Формулювання цілей статті. Метою статі $\epsilon$ обгрунтування та розроблення теоретико-методичних засад ідентифікації ризиків будівництва та експлуатації автомобільних доріг загального користування на основі побудови їх класифікації за окремими ознаками.

Виклад основного матеріалу дослідження. У більшості випадків поняття ризику у науковій літературі ототожнюється 3 усвідомленням небезпеки, будь-якою загрозою, непевністю через брак і неповноту наявної інформації тощо. Отже, ризик як явище $є$ негативним проявом настання або ненастання тієї чи іншої події, а його сутність є багато варіативною та такою, що асоціюється зі збитками.

Причинами ризику від будівництва та експлуатації автомобільних доріг в Україні $є$ дія певної комбінації факторів зовнішнього та внутрішнього середовища підприємств дорожнього господарства, яка характеризується високим ступенем невизначеності та турбулентності. При цьому, дорожнє господарство безпосередньо перебуває у стані постійної трансформації, що вимагає від нього швидкої реакції та гнучкої системи менеджменту на усіх рівнях управління. Специфічну природу ризику будівництва та експлуатації автомобільних доріг зумовлено особливостями продукції та послуг означених підприємств, зокрема, стаціонарністю об'єктів дорожнього будівництва, мінливістю природних умов, динамічністю транспортних потоків i впливу суб'єктів дорожньо-транспортної інфраструктури тощо.

Таким чином, під ідентифікацією ризиків будівництва та експлуатації автомобільних доріг загального користування будемо розуміти процес визначення того чи іншого ризику за його основною видовою характеристикою та подальше віднесення його до групування у відповідній класифікації.

Побудова означеної класифікації відбувається на засадах системного підходу, що розглядає дорожнє виробництво як складну сукупність будівельних об'єктів і будівельних організацій, їх основних виробничих фондів, кошторисних схем розрахунків, сукупності нормативних документів, інвестиційних проєктів, тендерних договорів та інших елементів системи. Тобто предмет ідентифікації ризиків будівництва та експлуатації автомобільних доріг - це діяльність виробничих систем в дорожньому будівництві, які виступають складними динамічними системами, складаються 3 низки підсистем, можуть входити в надсистеми, а також взаємодіяти 3 іншими системами та навколишнім середовищем. При цьому така властивість системи, як динамічність полягає в наступних безперервних змінах: станів об'єктів 
дорожнього будівництва й експлуатації, економічних та інвестиційних умов для кожного з таких об'єктів, цілей розвитку суб'єктів управління, безлічі станів зовнішнього середовища тощо.

За цих умов ідентифікація ризиків будівництва та експлуатації автодоріг відбуватиметься за наступною класифікацією (табл. 1).

Таблиия 1

Класифікація видів ризиків будівництва та експлуатації автомобільних доріг загального користування

\begin{tabular}{|c|c|}
\hline Класифікаційна ознака & Види ризиків \\
\hline 1 & 2 \\
\hline \multirow{2}{*}{$\begin{array}{l}\text { За походженням факторів } \\
\text { ризику }\end{array}$} & Екзогенні ризики \\
\hline & Ендогенні ризики \\
\hline \multirow{7}{*}{$\begin{array}{l}\text { За функціональними } \\
\text { напрямами }\end{array}$} & Будівельні ризики \\
\hline & Експлуатаційні ризики \\
\hline & Інвестиційні ризики \\
\hline & Інноваційні ризики \\
\hline & Фінансові ризики \\
\hline & Управлінські ризики \\
\hline & Кадрові ризики \\
\hline \multirow{6}{*}{ За фінансовим походженням } & Бюджетні ризики \\
\hline & Кредитні ризики \\
\hline & Інвестиційні ризики \\
\hline & Портфельні ризики \\
\hline & Ризики самофінансування \\
\hline & Валютні ризики \\
\hline \multirow{7}{*}{$\begin{array}{l}\text { За факторами } \\
\text { макросередовища }\end{array}$} & Географічні ризики \\
\hline & Демографічні ризики \\
\hline & Політичні ризики \\
\hline & Техніко-технологічні ризики \\
\hline & Економічні ризики \\
\hline & Нормативно-правові ризики \\
\hline & Екологічні ризики \\
\hline \multirow{4}{*}{$\begin{array}{l}\text { За відношенням до } \\
\text { будівельного процесу }\end{array}$} & Ризики підготовки до будівництва \\
\hline & Ризики будівництва \\
\hline & Ризики експлуатації \\
\hline & Ризики реалізації продукції будівництва \\
\hline \multirow{8}{*}{$\begin{array}{l}\text { За взаємодією } \\
3 \text { природним середовищем }\end{array}$} & Ризики взаємодії з людиною \\
\hline & Ризики взаємодії з флорою \\
\hline & Ризики взаємодії з фауною \\
\hline & Ризики взаємодії з повітрям \\
\hline & Ризики взаємодії з водним середовищем \\
\hline & Ризики взаємодії з грунтом \\
\hline & Ризики взаємодії з ландшафтом \\
\hline & Ризики взаємодії з кліматом \\
\hline \multirow{3}{*}{$\begin{array}{l}\text { За фазами життєвого } \\
\text { циклу об’єкту }\end{array}$} & Передінвестиційні ризики \\
\hline & Інвестиційні ризики \\
\hline & Експлуатаційні ризики \\
\hline
\end{tabular}


Продовження таблиці 1

\begin{tabular}{|c|c|}
\hline \multirow{9}{*}{$\begin{array}{l}\text { За приналежністю до } \\
\text { будівельної галузі }\end{array}$} & Ризики підрядного ринку \\
\hline & Ризик перевищення кошторису \\
\hline & Ризик несвоєчасного завершення термінів засвоєння інвестицій \\
\hline & Ризик порушення умов договору \\
\hline & Експлуатаційні ризики \\
\hline & Виробничі ризики (ризики провадження БМР) \\
\hline & Ризик невиконання МТ3 \\
\hline & Ризик менеджменту \\
\hline & Форс-мажорний ризик \\
\hline \multirow{5}{*}{$\begin{array}{l}\text { За процесом реалізації } \\
\text { основної діяльності }\end{array}$} & Підрядні ризики \\
\hline & Технічні ризики \\
\hline & Організаційні ризики \\
\hline & Управлінські ризики \\
\hline & Зовнішні ризики \\
\hline \multirow{4}{*}{$\begin{array}{l}\text { За суб'єктом екологічного } \\
\text { впливу }\end{array}$} & Ризики дорожньо-транспортного руху \\
\hline & Ризики дорожніх споруд \\
\hline & Ризики техніко-технологічних дорожніх процесів \\
\hline & Ризики дорожнього сервісу \\
\hline \multirow{5}{*}{ За проєктним характером } & Ризики вишукування та проєктування \\
\hline & Ризики узгодження проєкту \\
\hline & Адміністративні ризики \\
\hline & Ризики будівництва \\
\hline & Ризики експлуатації \\
\hline \multirow{6}{*}{ За стейкхолдерами } & Ризик власника об’єкту \\
\hline & Ризик власника проєкту \\
\hline & Ризик бізнес-структур \\
\hline & Ризик підрядника \\
\hline & Ризик громади \\
\hline & Ризик держави \\
\hline
\end{tabular}

Джерело: розробка авторів

Наведена класифікація $є$ спробою систематизації та розмежування наявної інформації щодо співвідношення видів ризику між собою, їх видовими характеристиками, приналежністю ризиків будівництва та експлуатації автодоріг за окремими категоріями (ознаками). Зазначені в табл. 1 види ризиків надалі доцільно розмежувати за підвидами та підсистемами функціонування виробничих підсистем дорожнього господарства. Водночас, запропонована класифікація дозволяє ідентифікувати приналежність певного ризику не тільки до однієї видової категорії, що забезпечує її гнучкість і адаптивність до запитів та інтересів дослідників.

Крім того, така класифікація $є$ уніфікованим теоретико-методичним забезпеченням побудови моделей прогнозування ризиків будівництва та експлуатації автомобільних доріг загального користування, що надає можливість здійснювати їх кількісне та якісне оцінювання.

Висновки 3 проведеного дослідження. Таким чином, системний підхід до визначення об'єктно-суб' єктних характеристик категорії ризику має прояв певних класифікаційних ознак (за походженням факторів ризику, за відношенням до будівельного процесу, за приналежністю до будівельної галузі, за стейкхолдерами тощо). Здійснюючи управління ризиками за можливими 
прогнозними моделями, побудованими на засадах відбору факторів в межах запропонованої класифікації, є можливою оптимізація управлінського вибору ризик-менеджментом у дорожньому господарстві. При цьому, вірогідність досягнення очікуваного результату від будівництва та експлуатації автомобільних доріг матиме тенденції наближення до прогнозних показників. Запропонована ідентифікація ризиків за класифікаційними ознаками $\epsilon$ основним етапом управління ризиками в дорожньому господарстві, подальшим розвитком якої є розгалуження підвидової типології ризиків та оцінювання ймовірності настання ризикової події для кожного з них.

\section{Перелік посилань}

1. Воскобіник О. П., Семко О. В. Сучасний стан проблеми керування технічними ризиками (ризик-менеджмент) у будівництві. Збірник наукових праць Полтавського національного технічного університету імені Юрія Кондратюка. Серія: галузеве машинобудування, будівництво. 2015. Вип. 1(43). C. 35-44.

2. Канін О. П, Татусь В. В. Ризики в проектах автомобільних доріг. Автомобільні дороги і дорожне будівнищтво. 2012. Вип. 86. С. 271-277 : сайт. URL : http://nbuv.gov.ua/UJRN/adidb_2012_86_33 (дата звернення 01.02.2020).

3. Свідрик Т. І., Борщук I. В. Фінансові ризики в будівельних проектах: сутність, причини виникнення, страхування : сайт. URL : https://nv.nltu.edu.ua/Archive/2006/16_6/258_Swidryk_16_6.pdf (дата звернення 30.01.2020).

4. Капінус К. В., Серьогін С. С. Страхування фінансових ризиків будівельно-монтажних робіт в Україні. Економіка $і$ Фінанси. 2017. № 11. С. 7078 : сайт. URL : https://journals.indexcopernicus.com/api/file/viewByFileId/261761. $\operatorname{pdf}$ (дата звернення 02.02.2020).

5. Корнієцький О. В. Оцінка економічної ефективності автомобільного будівництва доріг в умовах приватного інвестування. Украӥнський журнал прикладної економіки. 2018. Том 3. № 4. С. 192-198 : сайт. URL : http://ujae.org.ua/wp-content/uploads/2019/10/ujae_2018_r04_a22.pdf (дата звернення 02.02.2020).

6. Цімошинська $\quad$ О. В. Турбулентність інвестування проектів 3 будівництва та ремонту автомобільних доріг загального користування. Інвестиції: практика та досвід. 2018. № 21/2018. С. 5-10 : сайт. URL : http://www.investplan.com.ua/pdf/21_2018/3.pdf (дата звернення 01.02.2020). DOI: https://doi.org/10.32702/23066814.2018.21.5.

7. Рутковська I. А., Герасименко А. В., Зюзюн В. І. До створення моделі управління екологічними ризиками в інвестиційних проектах будівництва та реконструкції доріг. Науково-виробничий журнал «Автошляховик України». 2017. № 1-2(249-250). С. 69-72.

8. Богінська Л. О., Юрченко О. В. Формування організаційноекономічного механізму забезпечення екологічної безпеки дорожнього господарства. Науковий вісник Ужгородського національного університету. Серія «Економіка». 2017. Ч. 1. С. 171-176. 
9. Зюзюн В. І. Системна модель управління екологічними ризиками в проектах. Вісник Наџіонального транспортного університету. 2016. Випуск 2 (35). C. 84-92.

\section{References}

1. Voskobinik, O. P., Semko, O. V. (2015), "The current condition of the problem of technical risk management (risk management) in construction" ["Suchasny`j stan problemy` keruvannya texnichny`my' ry`zy`kamy' (ry`zy`kmenedzhment) u budivny`cztvi"], Collection of scientific works of Poltava Yuri Kondratyuk National Technical University. Series: industry engineering, construction, No. 1(43), P. 35-44.

2. Kanin, O. P, Tatus, V. V (2012), "Risks in road projects" ["Ry`zy`ky` v proektax avtomobil'ny`x dorig"], Highways and road construction, No. 86, P. 271277, available at : http://nbuv.gov.ua/UJRN/adidb_2012_86_33 (last accessed 01.02.2020).

3. Svidryk, T. I., Borschuk, I. V., Financial risks in construction projects: nature, causes, insurance [Finansovi ry`zy`ky` $\mathrm{v}$ budivel`ny`x proektax: sutnist`, pry`chy`ny` vy`ny`knennya, straxuvannya], available at https://nv.nltu.edu.ua/Archive/2006/16_6/258_Swidryk_16_6.pdf (last accessed 30.01.2020).

4. Kapinus, K. V., Seryogin, S. S. (2017), "Insurance of financial risks of construction works in Ukraine" ["Straxuvannya finansovy'x ry'zy'kiv budivel'nomontazhny'x robit v Ukrayini"'], Economics and Finance, No. 11, P. 70-78, available at : https://journals.indexcopernicus.com/api/file/viewByFileId/261761.pdf (last accessed 02.02.2020).

5. Kornietskiy, O. V. (2018), "Estimation of economic efficiency of road construction in the conditions of private investment" ["Ocinka ekonomichnoyi efekty`vnosti avtomobil'nogo budivny`cztva dorig $\mathrm{v}$ umovax pry`vatnogo investuvannya"], Ukrainian Journal of Applied Economics, Vol. 3, No. 4, P. 192-198, available at : http://ujae.org.ua/wp-content/uploads/2019/10/ujae_2018_r04_a22.pdf (last accessed 02.02.2020).

6. Tsimoshinskaya, O.V. (2018), "Turbulence of investing in projects for construction and repair of public roads" ["Turbulentnist' investuvannya proektiv z budivny'cztva ta remontu avtomobil'ny'x dorig zagal'nogo kory`stuvannya"], Investment: practice and experience, No. 21/2018, P. 5-10, available at : www.investplan.com.ua/pdf/21_2018/3.pdf (last accessed 01.02.2020), DOI: https://doi.org/10.32702/23066814.2018.21.5.

7. Rutkovskaya, I. A., Gerasimenko, A. V., Zyuzyun, V. I. (2017), “Towards the creation of a model of environmental risk management in investment projects for construction and reconstruction of roads" ["Do stvorennya modeli upravlinnya ekologichny`my` ry`zy`kamy` $\mathrm{v}$ investy`cijny`x proektax budivny`cztva ta rekonstrukciyi dorig"], The scientific-production journal "Road sector worker of Ukraine”, No. 1-2(249-250), P. 69-72.

8. Boginskaya, L. O., Yurchenko, O. V. (2017), "Formation of organizational and economic mechanism of ensuring the ecological safety of the road economy" 
["Formuvannya organizacijno-ekonomichnogo mexanizmu zabezpechennya ekologichnoyi bezpeky` dorozhn`ogo gospodarstva"], Scientific Bulletin of Uzhgorod National University. Economy series, Vol. 1, P. 171-176.

9. Zyuzyun, V. I. (2016), "System model of environmental risk management in projects" ["Sy`stemna model upravlinnya ekologichny`my` ry`zy`kamy” v proektax"], Bulletin of the National Transport University, Vol. 2 (35), P. 84-92.

\section{РЕФЕРАТИ РЕФЕРАТЫ ABSTRACTS}

\section{УДК 658.272:625.27; JEL Classification: R 42}

Деділова Т.В., Юрченко О.В. ІДЕНТИФІКАЦІЯ РИЗИКІВ БУДІВНИЦТВА ТА ЕКСПЛУАТАЦЇ̈ АВТОМОБІЛЬНИХ ДОРІГ

Мema. Метою статі $€$ обгрунтування та розроблення теоретикометодичних засад ідентифікації ризиків будівництва та експлуатації автомобільних доріг загального користування на основі побудови їх класифікації за окремими ознаками. Методика дослідження. В роботі використано наступні методи: метод теоретичного узагальнення (для визначення категорії «ідентифікація ризиків будівництва та експлуатації автомобільних доріг загального користування»); діалектичний метод (при формулюванні предмету ідентифікації ризиків будівництва та експлуатації автодоріг); системний підхід та загальнонауковий метод аналізу (для розроблення класифікації видів ризиків будівництва та експлуатації автодоріг). Результати. В дослідженні розглянуто актуальні теоретико-методичні питання ідентифікації ризиків будівництва та експлуатації автомобільних доріг загального користування. Надано авторське трактування поняттю «ідентифікація ризиків будівництва та експлуатації автомобільних доріг загального користування» як процесу визначення ризику за його основною видовою характеристикою та віднесення його до групування у відповідній класифікації. Окремо визначено предмет такої ідентифікації: діяльність виробничих систем в дорожньому будівництві, що є складними динамічними системами, складаються 3 низки підсистем, можуть входити в надсистеми, а також взаємодіяти 3 іншими системами та навколишнім середовищем. Розроблено класифікаційну таблицю видів ризиків будівництва та експлуатації автомобільних доріг загального користування. Наголошено на необхідності застосування такої класифікації як основи побудови прогнозних моделей ризикменеджменту в дорожньому господарстві. Наукова новизна. Отримав подальший розвиток теоретико-методичний підхід до управління ризиками в дорожньому господарстві шляхом їх ідентифікації при будівництві та експлуатації автомобільних доріг загального користування згідно розподілу за класифікаційними ознаками. Практична значущість. Результати дослідження можуть слугувати основою для розроблення методичних рекомендацій органам державного управління в галузі дорожнього будівництва та розвитку транспортної мережі регіону, суб'єктам Укравтодору, що безпосередньо 
здійснюють дорожнє виробництво, для оцінювання ймовірності настання ризикових подій.

Ключові слова: дорожне господарство; автомобільна дорога; ризики; управління; будівництво; експлуатація; класифікація; ідентифікація.

\section{УДК 658.272:625.27; JEL Classification: R 42}

Дедилова Т.В., Юрченко О.В. ИДЕНТИФИКАЦИЯ РИСКОВ СТРОИТЕЛЬСТВА И ЭКСПЛУАТАЦИИ АВТОМОБИЛЬНЫХ ДОРОГ

Цель. Целью статьи является обоснование и разработка теоретикометодических основ идентификации рисков строительства и эксплуатации автомобильных дорог общего пользования на основе построения их классификации по отдельным признакам. Методика исследования. В работе использованы следующие методы: метод теоретического обобщения (для определения категории «идентификация рисков строительства и эксплуатации автомобильных дорог общего пользования»); диалектический метод (при формулировке предмета идентификации рисков строительства и эксплуатации автодорог); системный подход и общенаучный метод анализа (для разработки классификации видов рисков строительства и эксплуатации автодорог). Pезультаты. В исследовании рассмотрены актуальные теоретикометодические вопросы идентификации рисков строительства и эксплуатации автомобильных дорог общего пользования. Представлена авторская интерпретация понятия «идентификация рисков строительства и эксплуатации автомобильных дорог общего пользования» как процесс определения риска по его основной видовой характеристике и отнесения к соответствующей видовой группировке в классификации. Отдельно определен предмет такой идентификации: деятельность производственных систем в дорожном строительстве, являющихся сложными динамическими системами, состоящими из ряда подсистем, такими, что могут входить в надсистемы, а также взаимодействовать с другими системами и окружающей средой. Разработана классификационная таблица видов рисков строительства и эксплуатации автомобильных дорог общего пользования. Отмечена необходимость применения такой классификации в качестве основы построения прогнозных моделей риск-менеджмента в дорожном хозяйстве. Научная новизна. Получил дальнейшее развитие теоретико-методический подход к управлению рисками в дорожном хозяйстве путем их идентификации при строительстве и эксплуатации автомобильных дорог общего пользования согласно распределению по классификационным признакам. Практическая значимость. Результаты исследования могут служить основой для разработки методических рекомендаций органам государственного управления в области дорожного строительства и развития транспортной сети региона, а также субъектам Укравтодора, непосредственно осуществляющим дорожное производство, для оценивания вероятности наступления рисковых событий.

Ключевые слова: дорожное хозяйство; автомобильная дорога; риски; управление; строительство; эксплуатация; классификация; идентификация. 


\section{UDC 658.272:625.27; JEL Classification: R 42}

\section{Dedilova T, Yurchenko O. IDENTIFICATION OF ROAD CONSTRUCTION AND OPERATION MAINTENANCE RISKS}

Purpose. The purpose of the article is to substantiate and develop the theoretical and methodological bases for identifying the public road construction and operation maintenance risks. Methodology of research. The following methods were used in the research. The generalization method was relevance to determine the category "identification of public road construction and operation maintenance risks". The dialectical method was used for formulating the subject of identification of public road construction and operation maintenance risks. The system approach and general scientific method of analysis were used to develop a classification of types of road construction and operation maintenance risks. Findings. The research considers actual theoretical and methodological questions of identifying the public road construction and operation maintenance risks. The author's interpretation of the concept "identification of the public road construction and operation maintenance risks" as a process of determining the risk by its main species characteristic and attributing it to the grouping in the appropriate classification was given. The subject of such identification was defined separately: the activities of production systems in road construction, which are complex dynamic systems, consist of a number of subsystems, can enter into over-systems, as well as interact with other systems and the environment. The classification table of types of risks of construction and operation maintenance of public roads has been developed. The necessity of using this classification as the basis for building predictive models of risk management in the road economy was noted. Originality. The theoretical and methodological approach to risk management in the road economy was further developed by identifying them in the construction and operation of public roads according to their classification criteria. Practical value. The results of the research can be used as guidelines for the public administration in the field of road construction and development of the transport network of the region, and for Ukravtodor entities directly engaged in road production, to assess the probability of occurrence of risk case.

Key words: road economy; road; risks; management; construction; operation maintenance; classification; identification.

\section{Відомості про авторів / Сведения об авторах / About the Authors}

Деділова Тетяна Вікторівна - кандидат економічних наук, доцент, Харківський національний автомобільно-дорожній університет, доцент кафедри економіки і підприємництва, м. Харків, Україна; e-mail: dedilova@ukr.net; ORCID: https://orcid.org/0000-0002-3924-979X. Моб. 050-281-83-28. 
Дедилова Татьяна Викторовна - кандидат экономических наук, доцент, Харьковский национальный автомобильно-дорожный университет, доцент кафедры экономики и предпринимательства, г. Харьков, Украина.

Dedilova Tetiana - PhD in Economics, Associate Professor, Kharkiv National Automobile and Highway University, Associate Professor of the Department of Economics and Entrepreneurship, Kharkiv, Ukraine.

Юрченко Оксана Вікторівна - кандидат економічних наук, Сумський національний аграрний університет, старший викладач кафедри будівельного виробництва, м. Суми, Україна; e-mail: kosareva_82@mail.ua. ORCID: https://orcid.org/0000-0001-6498-2339. Моб. 066-716-76-80.

Юрченко Оксана Викторовна - кандидат экономических наук, Сумской национальный аграрный университет, старший преподаватель кафедры строительного производства, г. Сумы, Украина.

Yurchenko Oksana - PhD in Economics, Sumy National Agrarian University, Senior Lecturer of the Department of Construction, Sumy, Ukraine. 